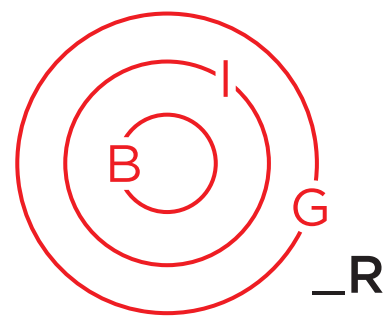

ART \& BORDERS

In English En français

\title{
Outline \& Depth of Otherness: An Interview with Randa Maroufi
}

\section{Contour et profondeur de l'altérité : Un entretien avec Randa Maroufi}

\section{Elisa Ganivet *}

In this interview, as part of the special section Art \& Borders, Art Editor Elisa Ganivet talks with the artist Randa Maroufi. The shore between Morocco and Europe is particularly questioned, along with Maroufi's fine work around the more structural, societal and gender boundaries. Her research is synthesized by stagings where a strong and clearsighted image predominates.

Dans cet entretien réalisé pour la section spéciale Art \& Borders, notre rédactrice Elisa Ganivet s'entretient ici avec l'artiste Randa Maroufi. La rive entre le Maroc et l'Europe est particulièrement questionnée. Tout comme l'est son fin travail tourné autour des frontières plus structurelles, sociétales et de genres. Ses recherches sont synthétisées par des mises en scène où prédomine une image forte et clairvoyante.

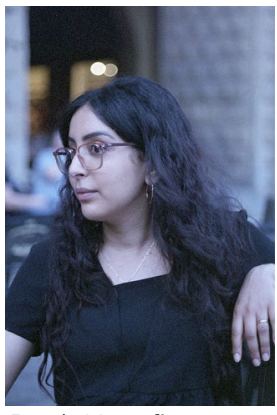

Randa Maroufi

www.randamaroufi.com

\section{About the artist}

Born in 1987 in Casablanca, Randa Maroufi currently lives and works in Paris. She is a graduate of the National Institute of Fine Arts, Tetouan, Morocco (2010) and the School of Fine Arts, Angers, France (2013). She also earned a diploma from Le Fresnoy Studio National des Arts Contemporains, Tourcoing, France (2015) and was an Artist Member of Academy of France in Madrid at Casa de Velázquez in 2017-2018.

Belonging to the generation that grew up in an era dominated by image, she collects them with as much eagerness as suspicion, and ceaselessly questions their veracity. She prefers to put her ambiguous fictions in the service of reality, and the field of her experimentation encompasses the occupation of public space and gender issues, of which she highlights the founding mechanisms.

Her work has been shown at art galleries and festivals around the world, and she has received many awards for her film Le Park (2015), and Bab Sebta (2019).

\section{A propos de l'artiste}

Née en 1987 à Casablanca, Randa Maroufi vit et travaille à Paris. Elle est diplômée de l'Institut National des Beaux-Arts de Tétouan, Maroc (2010), de l'École Supérieure des Beaux-Arts d'Angers, France (2013) ainsi que du Fresnoy - Studio National des Arts Contemporains, Tourcoing, France (2015). Randa Maroufi était membre artiste de l'Académie de France à Madrid - la Casa de Velázquez en 2017-2018.

Randa Maroufi s'intéresse à la mise en scène des corps dans l'espace public ou intime. Une démarche souvent politique, qui revendique l'ambiguité pour questionner le statut des images et les limites de la représentation.

Ses expositions récentes ont été présentées dans des galeries d'art et des festivals du monde entier, et elle a reçu de nombreux prix pour son film Le Park (2015) et Bab Sebta (2019).

\footnotetext{
* Elisa Ganivet, doctor of philosophy, art historian, author of Border Wall Aesthetics (Columbia University Press 2020), has worked as a cultural manager and curator for international public and private cultural organizations. Web: www.ElisaGanivet.com
} 
Elisa Ganivet: Randa, I have the feeling that the starting point of your aesthetic corpus was the positioning of the woman for structure and organic inquiry in society (with your performance Attempt of Seduction, 2013 and your installation Close Up, 2016), and that you naturally considered the place of the woman in the public space. In your photographic series Reconstitutions, 2016, the freeze-frames of scene before harassment and/or sexual tension are obvious and disturbing. These images may seem familiar and are, to say the least, revolting in what they imply as potential targets and underlying contempt.

With your photographic series and video Les intruses (The intruders), 2018-2019, you thwart the male mirror where women take possession of the street to simply make life, wait, or commit some mischief. This reversal of gender makes women visible in places where they are generally absent (cafés, fast-food, street corners, metro stations, or with traditinal male gestures, etc.), and it highlights idleness as well as petty activity (a theme also covered in The Park, 2015)

This artistic approach blurs the dichotomous male/female border. In the documentary and poetic look of the film The Great Safae, 2014, which evokes the transsexual housekeeper who worked in your family in Morocco-you take back this benevolence outside of any prejudice, outside of the hchouma, a notion between shame and modesty that is legion in traditional society. It seems to me that the analysis of these borders, first intimate and then societal, as well as your double experience in France and Morocco, naturally led you to an interest in a more geopolitical border. The one located in the enclave of Ceuta is symptomatic and you develop the related problems.

With the Around the Gate series, 2018 [Figure 1], we discover Bab Sebta exceptionally empty because the photographs were taken on a public holiday. Through the perspective of the volumes and the tones, the border zone is like a mirage, or even a set for a future dramatic film with the view of a few migrants who try to cross it in the backlight.

You propose another original reading thanks to the blue series of cyanotypes Diwana, 2018-2020. Here it is on the map that the customs are read with a psychogeographic application of the smugglers. They are the first to feel the territory they cross daily. This path is the reason for their financial survival. The meticulous details are captioned to facilitate our understanding. The cyanotype, photosensitive solution process, confers a preciousness that is justified by the risk they take.
Elisa Ganivet : Randa, j'ai l'impression que le point de départ de ton corpus esthétique avait pour pivot le positionnement de la femme, comme structure et questionnement organique dans la société (avec ta performance Attempt of seduction, 2013 et ton installation Close up, 2016) et que tu as naturellement considéré la place de la femme dans l'espace public. Dans ta série photographique Reconstitutions, 2016, les arrêts sur images de scène avant harcèlement et/ou tensions sexuelles sont manifestes et troublants. Ces images peuvent nous sembler familières et sont pour le moins révoltantes dans ce qu'elles supposent comme cibles potentielles et de mépris sous-jacent.

Avec ta série photographie et vidéo Les Intruses, 2018-2019, tu déjoues le miroir masculin où les femmes prennent possession de la rue pour simplement faire vie, attendre ou commettre quelques méfaits. Ce renversement des genres rend visible la femme là où elle est généralement absente (cafés, fast-foods, angles de rues, stations de métro, avec une gestuelle particulière etc.), et il met en exergue le désœuvrement tout comme le petit trafic (thématique également abordée dans Le Park, 2015).

Cette démarche artistique floute la frontière dichotomique homme/ femme. Dans le regard documentaire et poétique du film La Grande Safae, 2014, cette aide-ménagère transsexuelle qui exerça dans ta famille au Maroc, tu reprends cette bienveillance en dehors de tout préjugé, hors du "hchouma", notion entre honte et pudeur qui fait légion dans la société traditionnelle. II me semble que l'analyse de ces frontières d'abord intimes puis sociétales ainsi que ton expérience double en France et au Maroc t'ont naturellement conduites à t'intéresser à une frontière plus géopolitique. Celle située à l'enclave de Ceuta est symptomatique et tu en développes les problématiques afférentes.

Avec la série Around the gate, 2018 [Figure 1] on découvre Bab Sebta exceptionnellement vide car les photographies ont été prises un jour férié. Par la perspective des volumes et les tonalités, la zone frontalière s'apparente à un mirage, voire un décor pour un prochain film dramatique avec en contre-jour, la vue de quelques migrants qui tâchent de la franchir.

Tu proposes une autre lecture originale grâce à la série bleue des cyanotypes Diwana, 2018-2020. Ici c'est sur plan que la douane est lue avec une application psychogéographique des contrebandiers. Ces derniers sont les premiers à ressentir le territoire qu'ils traversent au quotidien. Ce trajet est la raison de leur survie financière. Les détails méticuleux sont légendés pour nous en faciliter la compréhension. Le cyanotype, procédé de solution photosensible, confère une préciosité justifiée par le risque qu'ils encourent.

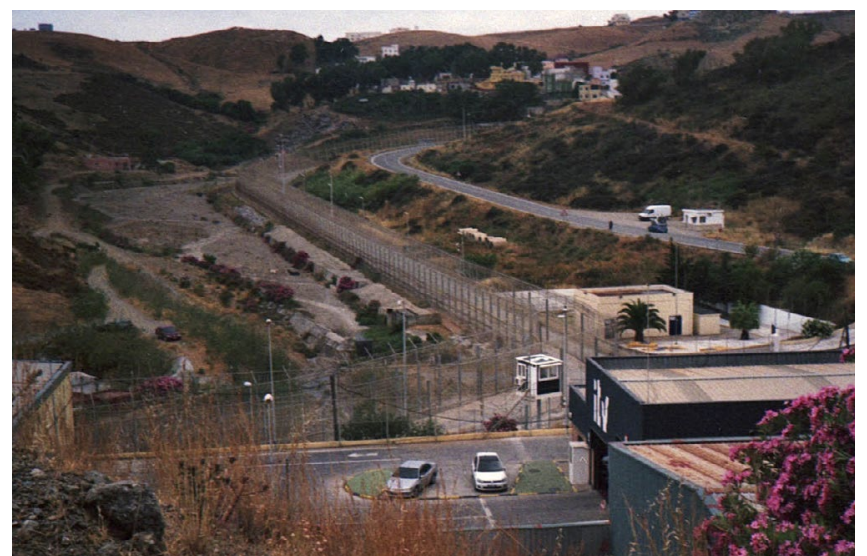

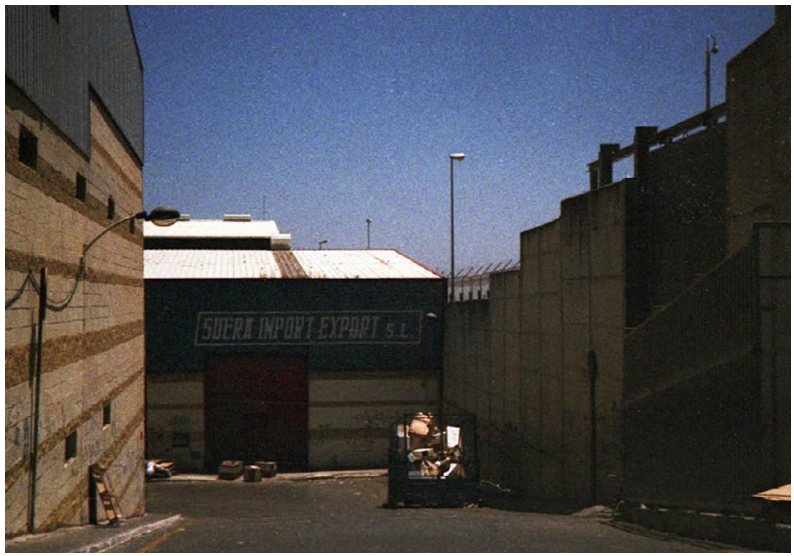

Figure 1. Excerpts from Around the Gate, 2019 (photo series). Prints on cotton paper, 308 grams, American box @ Randa Maroufi. 
Borders in Globalization Review | Volume 3 | Issue 1 | Fall/Winter 2021

Ganivet, "Outline \& Depth of Otherness: An Interview with Randa Maroufi"
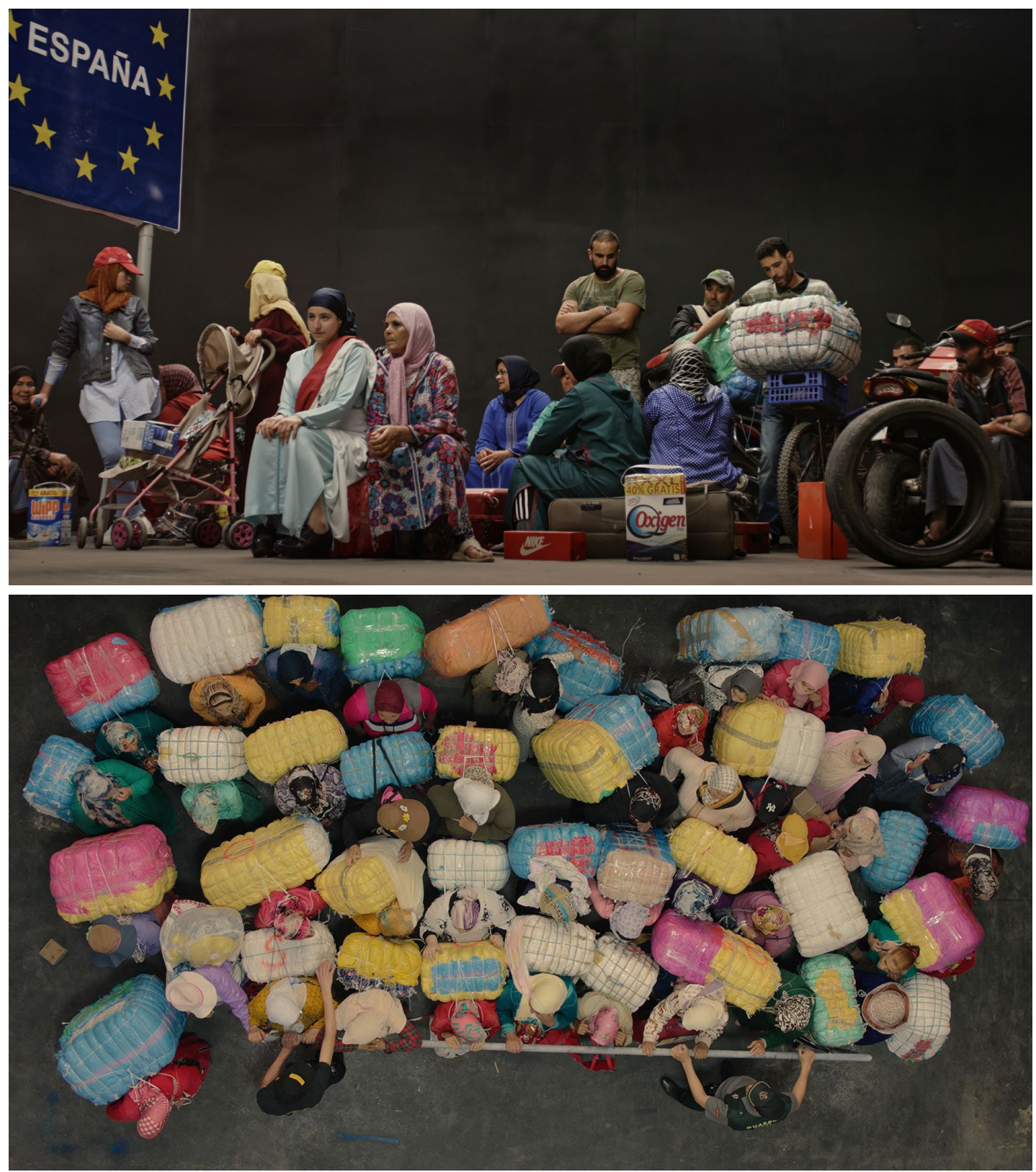

Figure 2. Excerpts from Bab Sebta, 2019. Short film, 19'. Production: Barney Production \& Montfleuri Production. With the support of: Fondation des Artistes, Doha Film Institute, CNC, Arab Fund for Arts and Culture, Casa de Velázquez, Le Fresnoy.

In the magnificent 2019 film Bab Sebta (Ceuta's Gate) [Figure 2], you focus on the activity of this border zone by putting in scene the main protagonists: smugglers, bi-national border police, customs officers. There is no denunciation, only a factual statement. The setting is gray, neutral, but the ground markings indicate strategic locations (tourist corridor, police stations, stopping zones, signs, etc.). They are complemented by equipment (cars, barriers, etc.). The flow of people is understood by slow dollies on the characters and by $180^{\circ}$ low angle views (by the way, do you know Alejandro Cartagena's 2014 Carpoolers series? ). In your film, we see in particular the mutual aid between the smugglers who ingeniously pack their colorful bundles well tied on their backs or hidden under their clothes. Voice-overs guide us, with first of all a policewoman of the Spanish border admitting herself that the choreography
Dans le magnifique film Bab Sebta, 2019 [Figure 2] tu t'attardes tout particulièrement à l'activité de cette zone frontalière en mettant en scène les principaux protagonistes: contrebandiers, police binationale de la frontière, douaniers. II n'y a aucune dénonciation simplement une énonciation factuelle. Le décor est gris, neutre, mais le marquage au sol signale les emplacements stratégiques (corridor des touristes, postes de police, zones d'arrêt, panneaux, etc.). Ils sont complétés par des équipements (voitures, barrières, etc.). Le flux des personnes se comprend par des lents travellings sur les personnages et par des vues en contreplongées à $180^{\circ}$ (à ce propos connais-tu la série Carpoolers, 2014 d'Alejandro Cartagena ?). Dans ton film, on voit en particulier l'entraide entre les contrebandières qui empaquettent ingénieusement leurs ballots colorés bien ficelés sur leurs dos ou cachés sous leurs vêtements. Des voix-off nous guident, avec tout d'abord une policière de la frontière espagnole avouant elle-même que la chorégraphie de 
of this zone is quite complex. How do you perceive this zone? Was the purpose of this project to untangle the threads?

Randa Maroufi: The sharing of public space is a common thread in my work, which I approach through actions or films. However I try not to limit myself to one subject or medium. I often have a main idea, and related ideas which come to graft. Moreover ambiguity is part of the means with which I play, both in The Great Safae or for Bab Sebta.

There is a porous border between documentary and fiction in my film productions, and this is also what allows me to take another look at my concerns, which are often social, societal and political. Indeed it also allows me to highlight the complexity of these issues; because the intimate and the social are very often linked, and they cohabit in most of my projects, both in the conception (the group work with the inhabitants/ actors of the spaces I study), and in the finished work. I try to have an approach which is situated between the reportage, the cinema and the sociological study.

This is particularly true in the Bab Sebta project, where the question of the border is at the heart of the subject, and for which several of my productions offer a view that is both universal and very intimate, as in Diwana, 2018-2019 [Figure 3], where drawings of the border are executed from memory by people who live there every day. In the film too, where the sequence shots, the travelling and the zenithal shots help me to play with the look and the point of view.

And I didn't know Alejandro Cartagena's work, I just discovered it in real life at Paris Photo and I find it very interesting! cette zone est bien complexe. Comment perçois-tu cette zone ? Ce projet avait-il pour dessein d'en démêler les fils?

Randa Maroufi : Le partage de l'espace public est un fil conducteur de mon travail, que j'appréhende via des actions ou des films. J'essaie cependant de ne pas me limiter à un propos ou à un médium. J'ai souvent une idée principale, et des idées connexes qui viennent se greffer. Par ailleurs, l'ambiguité fait partie des moyens avec lesquels je joue, à la fois dans La grande Safae ou pour Bab Sebta.

Il y a une frontière poreuse entre le documentaire et la fiction dans mes productions filmiques, et c'est aussi ce qui me permet de poser un autre regard sur mes préoccupations qui sont souvent d'ordre social, sociétal et politique. Cela me permet aussi de mettre en évidence la complexité de ces problématiques en effet car l'intime et le social sont très souvent liés, et ils cohabitent dans la plupart de mes projets, tant dans la conception (le travail de groupe avec les habitant.e.s/acteur.rice.s des espaces que j'étudie) que dans l'œuvre finie. Je tente d'avoir une approche qui se situe entre le reportage, le cinéma et l'étude sociologique.

C'est d'ailleurs ce que l'on retrouve particulièrement dans le projet Bab Sebta où la question de la frontière est au cœur du sujet, et pour laquelle plusieurs de mes productions proposent un regard à la fois universel et très intime, comme dans Diwana [Figure 3] où il s’agit de dessins de la frontière exécutés de mémoire par des personnes qui l'habitent au quotidien. Dans le film aussi, où les plans-séquences, les travellings et les plans zénithaux m’aident à jouer avec le regard et le point de vue.

Et je ne connaissais pas le travail d'Alejandro Cartagena, je viens de le découvrir en vrai à Paris photo et je le trouve très intéressant!

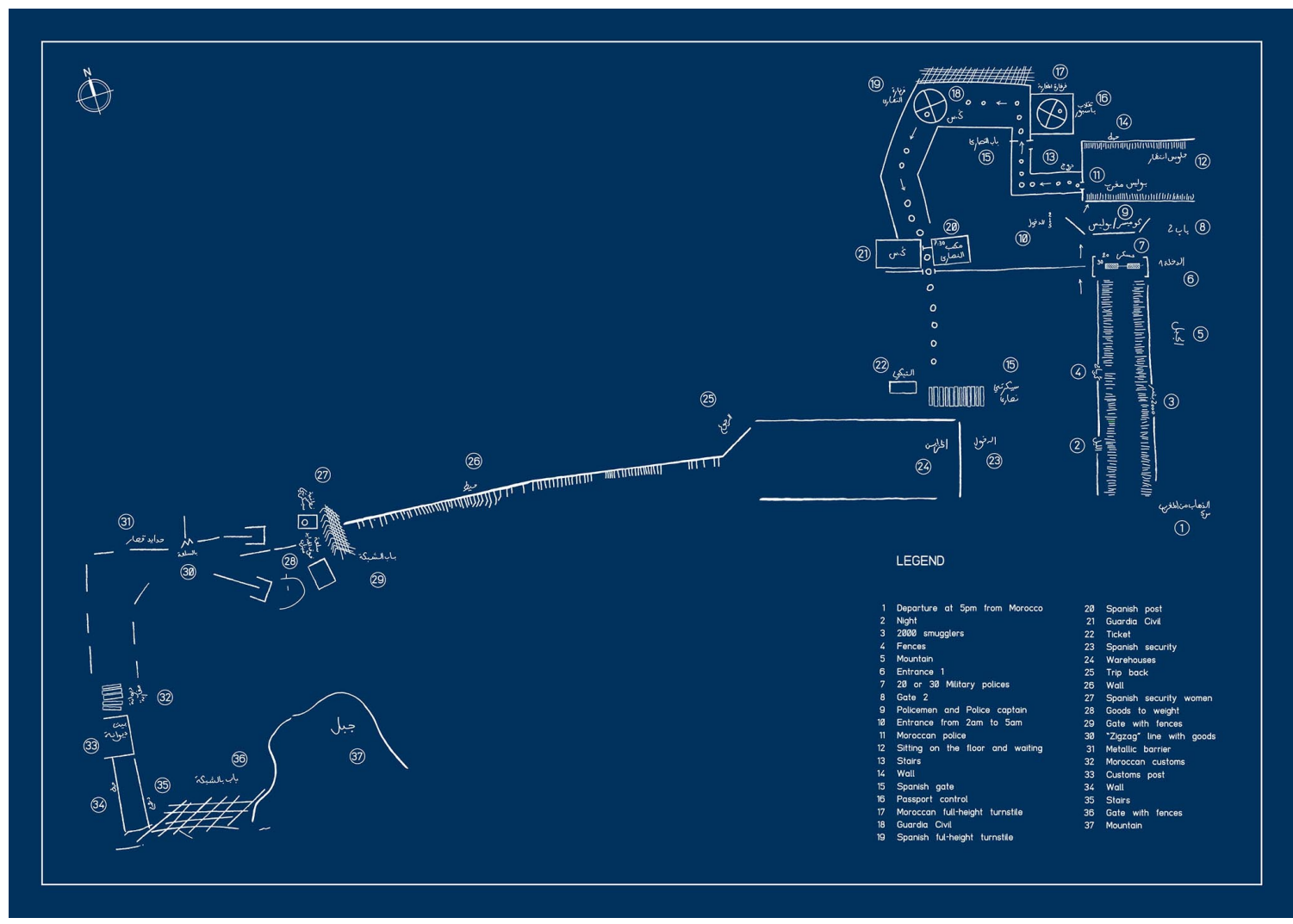

Figure 3. "Sans titre 5" from Diwana, 2018-2019 (series of cyanotype). Cyanotype on Velin d'Arches, 100 x 135.5 cm ( Randa Maroufi. 
EG: By the way, what was your reaction when last spring King Mohammed VI left the floodgates open at the border between Morocco and Spain? Was this really a means of pressure and a response to the medical aid granted to Brahim Ghali, dissident leader of the Polisario Front by Spain? The images were at least impressive.

RM: The migration issue is very complex, and in this event, the blame lies on both sides. Morocco has considered Sebta as an extension of Moroccan territory, but we are not fooled. It is mainly to put pressure on Europe and in this case on Spain, to the detriment of the inhabitants of Sebta who are part of the Moroccan people. Morocco could have taken a more intelligent and respectful approach, for example by putting pressure on the economy. On the other hand, Spain and Europe are playing on this situation by turning a blind eye to these issues and blaming Morocco for letting the people migrate to Europe and neglecting their protection. Certainly, Morocco has not acted well, but Europe is using this event to cover up its own abuses against migrant populations, which proves, as sociologist Mehdi Alioua (Associate Professor at the International University of Rabat, attached to "Sciences Po Rabat") reminds us, that this is not a migration crisis but a political crisis.

EG: Yes, thank you for mentioning here Professor Alioua, a specialist in the study of transnational and cross-border migratory movements between West Africa, the Maghreb and Europe.

Randa, in your work Bab Sebta, you reveal the exceptional figures of the women smugglers. They are visually stunning and were recently displayed all over Paris with posters for the exhibition "Zone Franche " at the $\mathrm{ICl}$, and you extend these images with the series of portraits Nabila \& Keltoum \& Khadija, 2015 [Figure 4]. How were you able to approach and convince all these workers to participate in your film? Do you have maybe any anecdotes to share with us?

RM: My projects are the result of discussions, interviews and meetings. Affinities and dialogues are created, and certain people quickly take an active part in the production. It's a team work that is set up in a rather organic way. For Bab Sebta, Nabila and Keltoum were essential to the project, and they guided me in the field and during my location scouting. For example, they recruited women to play smugglers without telling me that this was not their real activity, thinking that it would be a problem. I overheard them (later while I was logging the film) telling them the right things to do by whispering "to make it real". I found this funny but above all very interesting because it shows the women heads that they are, the importance that they had for the realization of the film on the one hand, and it confirmed to me on the other hand that the question of the ambiguity of the staging works.

EG: Similarly, you pay tribute to your father who was a customs inspector. Does the genesis of this project come from some childhood memories? Is this a triggering factor?

RM: My work around the border obviously touches on a part of my personal history, but to a degree that I want to control. I also grew up in the "world" of the frontier and several members of my family have worked there in some capacity. Some of my father's objects have inspired me to create works of art, such as the blue customs cloth that belonged to my father for the video Les plieurs (The Folders), 2021 [Figure 5], or the customs register that was a pivotal point in my thinking for the exhibition "L'autre comme hôte" (The Other as Host) at the Centre d'Art Contemporain Chanot in Clamart
EG : D'ailleurs quelle fut ta réaction lorsqu'au printemps dernier, le roi Mohammed VI a laissé les vannes ouvertes à la frontière entre le Maroc et l'Espagne ? S'agissait-il vraiment d'un moyen de pression et d'une réponse envers l'aide médicalisée octroyée à Brahim Ghali, chef dissident du front polisario par l'Espagne? Les images étaient tout du moins impressionnantes.

RM : La question migratoire est très complexe, et dans cet évènement, le blâme se situe des deux côtés. Le Maroc a considéré Sebta comme une extension du territoire marocain, mais nous ne sommes pas dupes. C'est surtout pour faire pression sur l'Europe et en l'occurrence sur l'Espagne, au détriment des habitant.e.s de Sebta qui font partie du peuple marocain. Le Maroc pouvait engager une démarche plus intelligente et respectueuse, en faisant pression sur l'économie par exemple. De l'autre côté, l'Espagne et l'Europe jouent de cette situation en fermant les yeux sur ces questions et en remettant la faute sur le Maroc pour avoir laissé les populations migrer vers l'Europe, et avoir négligé leur protection. Certes, le Maroc n'a pas bien agi, mais l'Europe utilise cet évènement pour maquiller ses propres exactions envers les populations migrantes, ce qui prouve bien, comme le rappelle le sociologue Mehdi Alioua (Professeur Associé de I'Université Internationale de Rabat, rattaché à « Sciences Po Rabat »), qu'il ne s'agit pas d'une crise migratoire mais d'une crise politique.

EG : Oui, merci d'évoquer ici le Professeur Alioua, spécialiste de l'étude des mouvements migratoires transnationaux et transfrontaliers entre l'Afrique de l'Ouest, le Maghreb et l'Europe.

Randa, dans ton œuvre Bab Sebta, tu révèles les figures exceptionnelles des contrebandières. Elles sont visuellement magnifiques et ont été récemment placardées dans tout Paris (affiches de l'exposition "Zone Franche » à l'ICl et tu prolonges ces images avec la série de portraits Nabila \& Keltoum \& Khadija, 2015 [Figure 4]. Comment as-tu pu approcher tous ces travailleurs et les convaincre de participer à ton film?

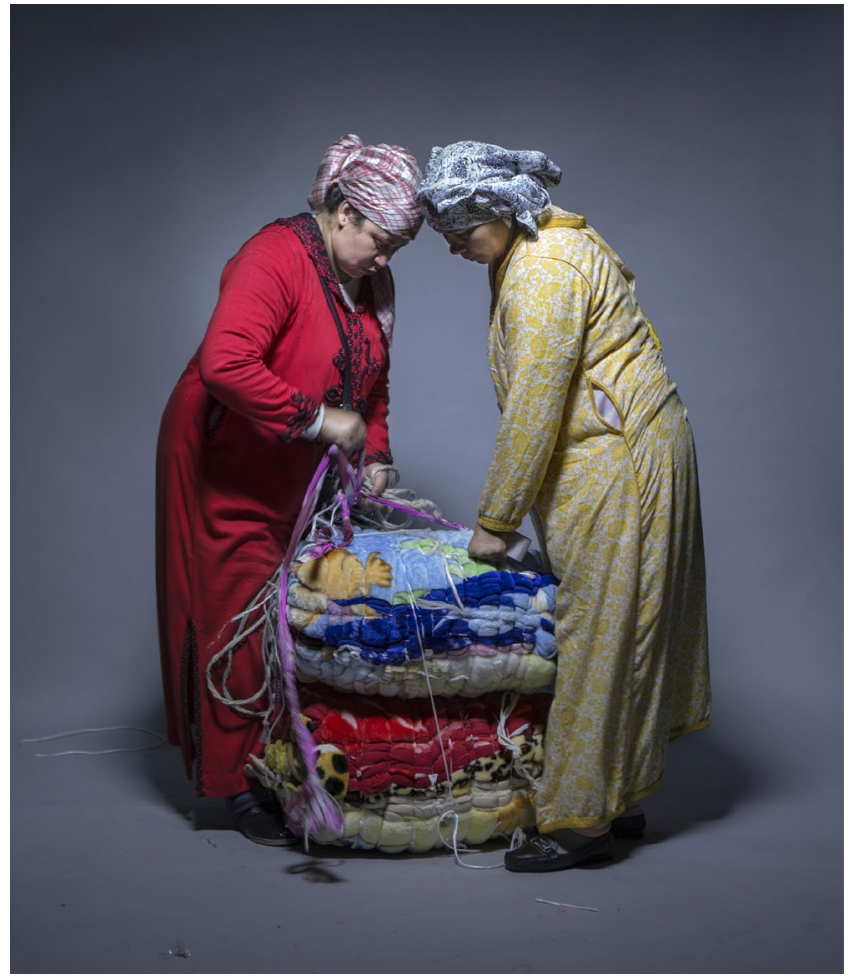

Figure 4. "Préparation" from Nabila \& Keltoum \& Khadija, 2015 (photo series). Colour Photography, (c) Randa Maroufi. 


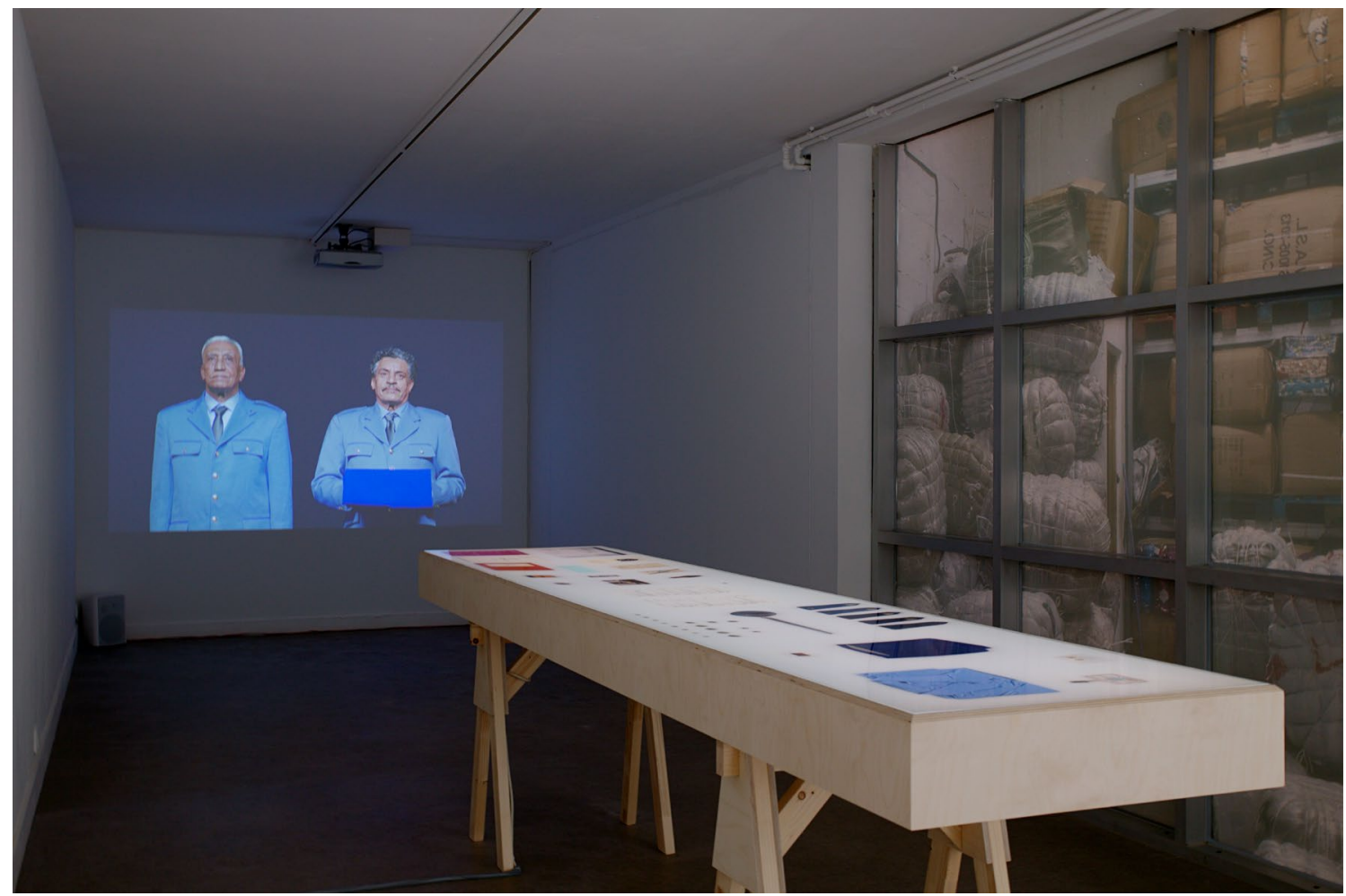

Figure 5. Les plieurs, 2021. Video, 9'. Coproduced by CACC Clamart $\odot$ Randa Maroufi. View of the exhibition 'l'autre comme hôte' by Randa Maroufi at CACC Clamart @ Tony Trichanh.

EG: Today, does your binational experience give you insight into the contradictions of each of these countries? There was a time when people talked a lot about cultural identity, what does this term inspire to you, is it still appropriate?

RM: The question of a "cultural identity" doesn't mean much, even less now. There is no dual experience but a common experience, histories and personal identities. It is from these shared experiences that I come to see more clearly what I am studying. Clarity rather than insight. It comes from my research and fieldwork, from dialogues and interviews with those who become the actors of my films.

I don't do politics, but my work has a political dimension. It is for me to pose and propose a glance on a social and political reality. It is not a question either of entering a frontal militant fight but of transmitting my vision in a soft and intelligent way, by playing with the codes, by diverting situations.

EG: Speaking of codes, how did the Stand-by Office, 2017 [Figure 6] project come about? Here, migrants living in Amsterdam cannot work but they have taken over an office. The absurdity of this inability to work is visually reproduced. We come back to the impossibility of integration, a discourse that monopolizes the discourse of Western societies. Could you explain your approach to us?

RM: I was on an art residency in Amsterdam. I was walking through the streets of the city and I noticed the words "We Are Here" on the surface of a building. I immediately thought it was a festive event, and then I saw Osman and Ahmed standing in front of it. I asked them what was going on here and they told me that they were part of a group of refugees living in empty buildings in the suburbs of Amsterdam. They invited me to discover the place, old disused
RM : Mes projets sont le fruit de discussions, d'entretiens et de rencontres. II se crée alors des affinités, des dialogues, et certaines personnes prennent vite une part active dans la production. C'est un travail en équipe qui se met en place de manière plutôt organique. Pour Bab Sebta, Nabila et Keltoum ont été essentielles au projet, et elles m'ont guidé sur le terrain et pendant mes repérages. Elles ont, par exemple, recruté des femmes pour jouer des contrebandières sans me dire que ce n'était pas leur activité réelle, pensant que ce serait un problème. Je les ai entendues (plus tard en dérushant le film) leur indiquer les bons gestes à avoir en chuchotant « pour faire vrai ». J'ai trouvé cela drôle mais surtout très intéressant parce que cela montre les femmes de têtes qu'elles sont, l'importance qu'elles ont eue pour la réalisation du film d'une part, et cela m'a confirmé, d'autre part, que la question de l'ambiguité de la mise en scène fonctionne.

EG : Pareillement, tu rends hommage à ton père qui était inspecteur des douanes. La genèse de ce projet viendrait-il de certains souvenirs d'enfance ? Est-ce là un fondement déclencheur ?

RM : Mon travail autour de la frontière touche évidemment à une part de mon histoire personnelle, mais à un degré que je souhaite maîtriser. J'ai par ailleurs grandi dans "l'univers" de la frontière et plusieurs membres de ma famille y ont travaillé de près ou de loin. Certains objets de mon père m'ont inspiré des œuvres, comme le tissu bleu de la douane qui appartenait à mon père pour la vidéo Les plieurs, 2021 [Figure 5] ou le registre de la douane qui a été un pivot dans ma réflexion pour l'exposition "L'autre comme hôte » au Centre d'Art Contemporain Chanot à Clamart.

EG : Aujourd'hui, ton expérience binationale t'apporte-t-elle une clairvoyance sur les contradictions propres à chacun de ces 

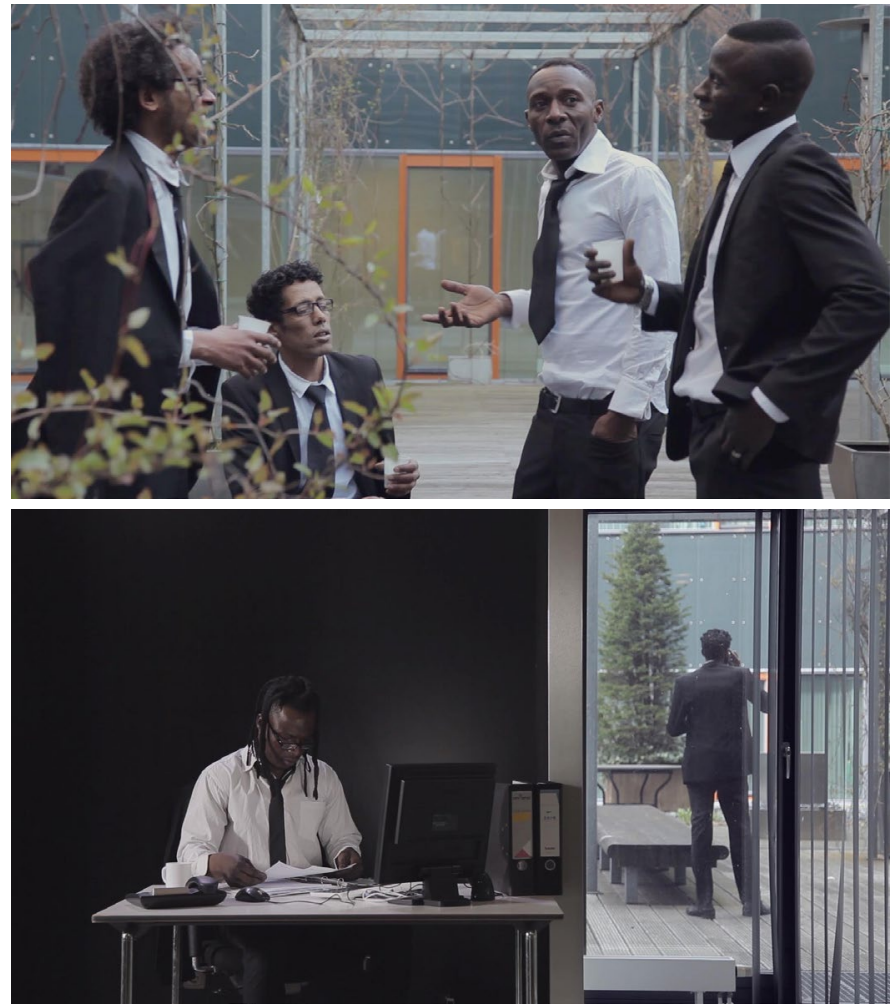

Figure 6. Stand-by Office, 2017. Video, 13'20”. In collaboration with the "We Are Here " group, Amsterdam. With the support of: Le Fresnoy, Culture Resource's Production Awards Program, CBK Zuidoost, Cinelabs Romania, Studio aux cuves dorées. (c) Randa Maroufi.

offices dating from the early 2000 s, serving as their living space. And yes, it is this contrast that struck me; and I wanted to create from this a fiction mixing personal history and history of the place.

I went back there every day for two months, to discuss, cook, play cards, and listen to music but mostly to kill time, I showed them my work and we thought together about what we could do with this place. They felt involved and, as is often the case, the bonds of trust were forged naturally, so we formed a working team. I also leave a lot of room for improvisation: this also plays a role in the fiction/documentary ambiguity.

The film works on the way refugees are represented and the role they are given. We see the person as a "migrant" first, we see the difficulties of life. We are presented with political measures rather than individual realities, with speeches that are locked into something alarmist.

As far as the impossibility of integration is concerned, it is the opposite that I am trying to show. The suit and tie is a western code, which implicitly justifies a legal status, a certain authority. Stand-by Office is in this sense a wink, and reverses the imaginary that serves as official history, to reveal an implicit reality and little shown.

EG: And what is the project Fragments d'un territoire (Fragments of a territory), 2020?

RM: It's a performance project where I wanted to reactivate elements used (costumes, sets, props, etc.) in the film Bab Sebta and with hindsight, I realize that it was more a response to a need to experiment in situ. pays ? II fut un temps, on parlait beaucoup d'identité culturelle, qu'est-ce que t'inspire ce terme, est-il encore approprié ?

RM : La question d'une « identité culturelle " ne veut pas dire grand-chose, encore moins à l'heure actuelle. II n'y a pas d'expérience double mais une expérience commune, des histoires et des identités personnelles. C'est à partir de ces expériences à plusieurs que je parviens à voir plus clairement l'objet que j'étudie. Clarté plutôt que clairvoyance. Elle me vient de mes recherches et de mes prospections de terrain, des dialogues et des entretiens avec ceux et celles qui deviennent les acteur.rice.s de mes films.

Je ne fais pas de la politique, mais mon travail a une dimension politique. II s'agit pour moi de poser et de proposer un regard sur une réalité sociale et politique. II n'est pas non plus question d'entrer dans un combat militant frontal mais de transmettre ma vision de manière douce et intelligente, en jouant avec les codes, en détournant des situations.

EG : En parlant de codes, comment a surgi le projet Stand-by Office, 2017 ? [Figure 6] lci des migrants installés à Amsterdam ne peuvent travailler mais ils ont investi un bureau. L'absurdité de cet empêchement à travailler est visuellement reprise. On en revient à l'impossibilité de l'intégration, discours qui monopolise le discours des sociétés occidentales. Pourrais-tu nous expliquer ta démarche?

RM : J'étais en résidence artistique à Amsterdam. Je marchais dans les rues de la ville et j'ai remarqué la mention "We Are Here » sur la surface d'un bâtiment. J'ai tout de suite pensé à un événement festif, puis j'ai vu Osman et Ahmed postés devant. Je leur ai demandé ce qu'il se passait ici et ils m'ont répondu qu'ils faisaient partie d'un groupe de réfugiés installés dans des bâtisses vides en banlieue d'Amsterdam. Ils m'ont invité à découvrir le lieu, des anciens bureaux désaffectés datant du début des années 2000, leur servant de lieu de vie. Et oui, c'est ce contraste qui m'a frappé ; et j'ai voulu créer à partir de ça une fiction mêlant histoire personnelle et histoire du lieu.

J'y suis retournée tous les jours pendant deux mois, pour discuter, cuisiner, jouer aux cartes, écouter de la musique mais surtout tuer le temps, je leur ai montré mon travail et nous avons pensé ensemble à ce qu'on pouvait faire de ce lieu. Ils se sont sentis impliqués et comme souvent, les liens de confiance se sont tissés naturellement, alors on a formé une équipe de travail. Je laisse aussi une grande place à l'improvisation : ça rentre aussi en compte dans l'ambiguité fiction/documentaire.

Le film travaille sur la manière dont les personnes réfugiées sont représentées et le rôle qu'on leur attribue. On voit d'abord la personne en tant que " migrante », on voit les difficultés de vie. On nous présente plutôt des mesures politiques que des réalités individuelles, des discours qui s'enferment dans quelque chose d'alarmiste.

Pour ce qui est de l'impossibilité de l'intégration, c'est tout le contraire que je cherche à montrer. Le costume/cravate est un code occidental, qui implicitement justifie d'un statut légal, d'une certaine autorité. Stand-by Office est dans ce sens un clin d'œil, et inverse l'imaginaire qui fait office d'histoire officielle, pour dévoiler une réalité implicite et peu montrée. 
EG: Are you still going to work on the theme of a more geopolitical border, of geostrategic stakes, and if so, which axis interests you more precisely? What have you learned from this field research?

RM: Why not. My projects cannot exist without my field research. So everything is to be learned.

EG: What is your current project?

RM: The project I am working on at the moment is called L'mina and is located in Morocco. It's a research project about an ex-mining city.

EG: Okay, so the immersion is in geological terrain, with social issues and economic and societal impacts around it. Thank you very much Randa for enlightening us on your fascinating work!
EG : Et qu'est-ce que le projet Fragments d'un territoire, 2020 ?

RM : C'est un projet de performance où je souhaitais réactiver des éléments utilisés (costumes, décors, accessoires, etc.) dans le film Bab Sebta et avec du recul, je me rends compte que ça répondait plutôt à un besoin d'expérimenter in situ.

EG : Vas-tu encore travailler sur la thématique d'une frontière plus géopolitique, d'enjeux géostratégiques, et si oui, quel est l'axe qui t'intéresse davantage ? Qu'as-tu appris de ces recherches de terrain?

RM : Pourquoi pas. Mes projets ne peuvent exister sans mes recherches de terrain. Tout est donc à apprendre.

EG : Quel est ton projet actuel ?

RM : Le projet sur lequel je travaille en ce moment s'intitule L'mina et se situe au Maroc. Il s'agit d'une recherche autour d'une ex-cité minière.

EG : D'accord, alors l'immersion est en terrain géologique, avec en pourtour les enjeux sociaux et les impacts économiques et sociétaux. Merci beaucoup Randa de nous avoir éclairés sur ton passionnant travail ! 